\title{
HDAC6 inhibition by tubastatin A is protective against oxidative stress in a photoreceptor cell line and restores visual function in a zebrafish model of inherited blindness
}

\author{
Janina Leyk ${ }^{1}$, Conor Daly ${ }^{2}$, Ulrike Janssen-Bienhold ${ }^{3}$, Breandán N. Kennedy ${ }^{2}$ and Christiane Richter-Landsberg*,1
}

Retinal diseases, such as hereditary retinitis pigmentosa and age-related macular degeneration, are characterized by the progressive loss of photoreceptors. Histone deacetylase 6 (HDAC6) is considered as a stress surveillance factor and a potential target for neuroprotection and regeneration. Overexpression of HDAC6 has been connected to neurodegenerative disorders, and its suppression may provide protection. Here we show that HDAC6 is constitutively present in the mouse retina, and in the cone-like mouse cell line 661W. In 661W cells HDAC6 inhibition by the specific inhibitor tubastatin A (TST) led to the acetylation of $\alpha$-tubulin, which is a major substrate for HDAC6. After oxidative stress, exerted by hydrogen peroxide, TST promoted cell survival and the upregulation of heatshock proteins HSP70 and HSP25 by activation of heat-shock transcription factor 1. Furthermore, in response to oxidative stress the redox regulatory protein peroxiredoxin 1 (Prx1) was modulated in 661W cells by HDAC6 inhibition. The peroxide reducing activity of Prx1 is dependent on its acetylation, which is mediated by HDAC6. Pre-incubation with TST prevented the inactivation of Prx1 and its preserved activity may exert protective effects in photoreceptor cells. To determine whether TST treatment has a therapeutic effect on visual function, the $d y e^{u c d 6}$ zebrafish model of inherited sight loss was utilized. Zebrafish have developed as a suitable model system for pharmacological testing. In vivo application of TST caused the hyperacetylation of $\alpha$-tubulin, indicating that HDAC6 is active in this model. Furthermore, TST was sufficient to rescue visual function and retinal morphology. Hence, HDAC6 inhibition and the regulation of peroxiredoxin activity may play a significant role in protecting retinal cells and in particular photoreceptors, which are exposed to high levels of reactive oxygen species derived from oxidative stress-induced injuries.

Cell Death and Disease (2017) 8, e3028; doi:10.1038/cddis.2017.415; published online 31 August 2017

Blinding conditions, such as retinitis pigmentosa (RP), agerelated macular degeneration and cone dystrophies (COD), are characterized by the progressive loss of photoreceptors. Despite the knowledge of causative mutations in 67 genes for RP and 25 genes for COD (RetNet: https://sph.uth.edu/retnet, date last accessed June 2017) no effective therapy is yet available. In RP, primary rod degeneration is followed by secondary cone cell death, and in COD cone photoreceptors are the major cells affected and subsequently degenerate. ${ }^{1,2}$ The molecular mechanisms leading to cone degeneration, however, are still unclear and need elucidation.

Oxidative stress, which is defined as an imbalance between the level of reactive oxygen species (ROS) and antioxidant defenses, ${ }^{3}$ is connected to retinal degeneration. Since cone photoreceptors have a high metabolic demand and are characterized by a high content of unsaturated lipids, they are particularly susceptible to ROS-induced cell damage.,5 Increasing evidence obtained from animal RP models as well as from analyses of aqueous humor from RP patients suggests that oxidative stress contributes to secondary cone death in RP pathogenesis. ${ }^{6,7}$ Furthermore, a variety of studies implicate that the application of antioxidants slows photoreceptor degeneration and promotes long-term survival of cones in mouse models of RP. ${ }^{8-10}$

In response to cellular stress situations, heat-shock proteins (HSPs) are induced. ${ }^{11,12}$ HSPs are highly conserved proteins that act as molecular chaperones and as a first line of defense against cellular stress; they are induced by transcription factors, such as heat-shock factor 1 (HSF1). ${ }^{13}$ Recent studies suggest a protective role for HSPs in degenerative processes of the retina. Parfitt et al. ${ }^{14}$ and Aguila et al. ${ }^{15}$ demonstrated that induction of a heat-shock response delayed degeneration of photoreceptors and restored visual function in the $\mathrm{P} 23 \mathrm{H}$ rat model for RP. Furthermore, heat-shock protein 70 (HSP70) induction may prevent photoreceptor cell death in rodent models of RP. ${ }^{16}$ Ischemic insults, oxidative stress and other factors induce the small heat-shock protein 27 (HSP27/ HspB1) in retinal cells, providing neuroprotection due to its molecular chaperone activity, interaction with the cytoskeleton and prevention of apoptotic cell death. ${ }^{17}$

Recently a role for histone deacetylases (HDACs) in retinal stress responses and degeneration emerged. ${ }^{18-20}$ Mammalian HDACs are divided into four classes (HDAC I-IV) according to their homology to yeast HDACs. Class I, II and

\footnotetext{
${ }^{1}$ Department of Neuroscience, Molecular Neurobiology, University of Oldenburg, Oldenburg D-26111, Germany; ${ }^{2}$ School of Biomolecular and Biomedical Science, Conway Institute, University College Dublin, Belfield, Dublin D04 V1W8, Ireland and ${ }^{3}$ Department of Neuroscience, Visual Neuroscience, University of Oldenburg, Oldenburg D-26111, Germany

${ }^{*}$ Corresponding author: C Richter-Landsberg, Department of Neuroscience, Molecular Neurobiology, University of Oldenburg, Molecular Neurobiology, POB 2503, Oldenburg D-26111, Germany. Tel: +49 441/798 3422; Fax: +49 441/798 3250; E-mail: Christiane.Richter.Landsberg@Uni-Oldenburg.de

Received 01.2.17; revised 19.7.17; accepted 24.7.17; Edited by A Verkhratsky
} 
a

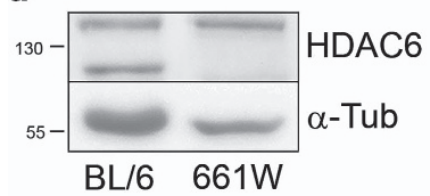

b

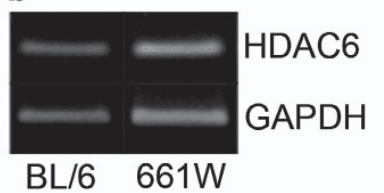

C

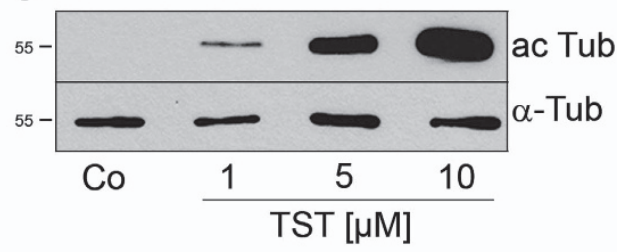

d ac Tub F-actin overlay with DAPI
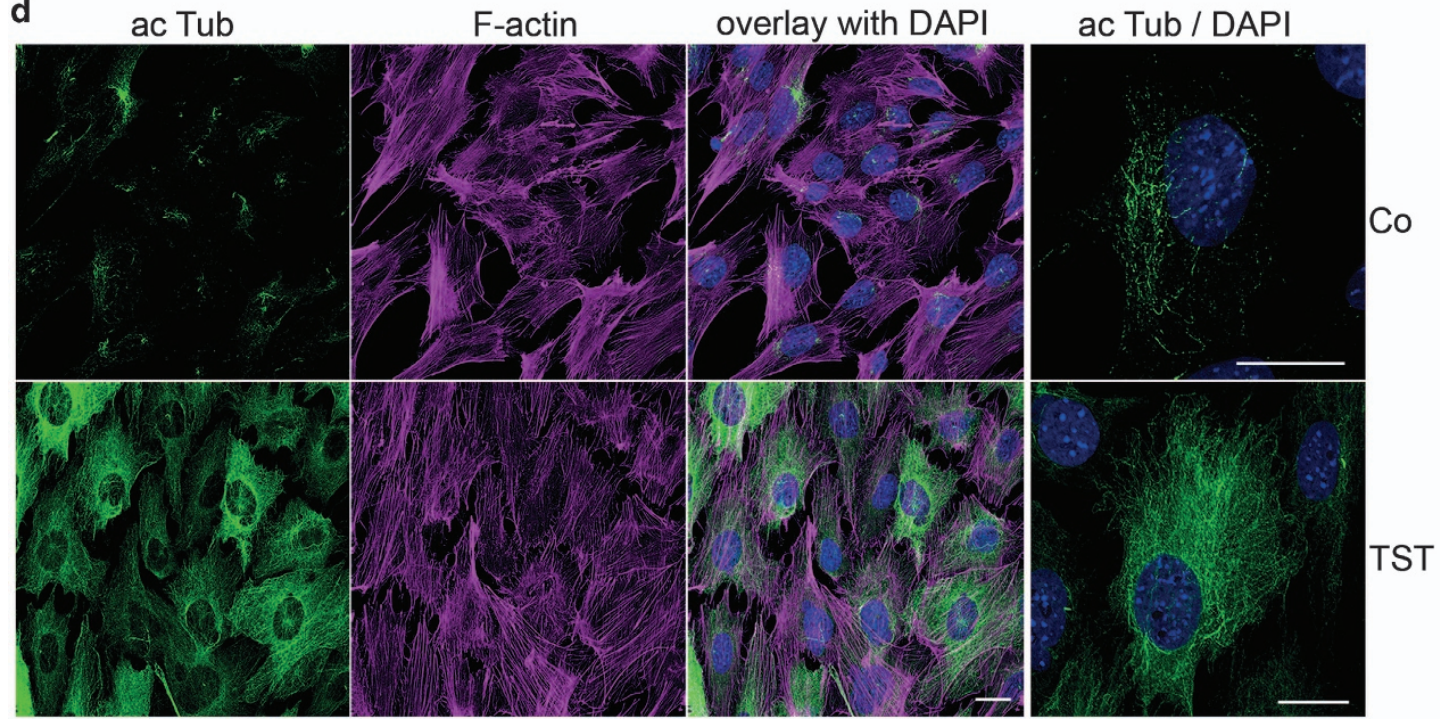

Figure 1 HDAC6 is expressed in mouse retinae and its inhibition by tubastatin A leads to hyperacetylation of $\alpha$-tubulin in $661 \mathrm{~W}$ cells. Immunoblot analysis (a) and RT-PCR analysis (b) revealed HDAC6 expression in lysates from C57BL/6J mouse retinae (BL/6) and 661W cells. $\alpha$-Tub, $\alpha$-tubulin. (c) Immunoblot analysis of $661 \mathrm{~W}$ cell extracts incubated with tubastatin A (1, 5 and $10 \mu \mathrm{M}$ ) for $24 \mathrm{~h}$ was carried out using antibodies against $\alpha$-tubulin ( $\alpha$-Tub) and acetylated tubulin (ac Tub). (d) $661 \mathrm{~W}$ cells were treated with $10 \mu \mathrm{M}$ tubastatin $\mathrm{A}$ (TST) for $24 \mathrm{~h}$. Indirect immunofluorescence was carried out using an antibody against acetylated tubulin (ac Tub) and Phalloidin-CF594 was used to label F-actin. Nuclei were stained with DAPI. Co, untreated control. High magnification images of $661 \mathrm{~W}$ cells revealed a pronounced increase of acetylated $\alpha$-tubulin in TST-treated cells. Scale bars: $20 \mu \mathrm{m}$

IV HDACs are zinc-dependent and structurally different from the $\mathrm{NAD}^{+}$-dependent class III HDACs, also known as sirtuins. ${ }^{21}$ Excessive activation of class I and II HDACs was observed in the rd1 mouse model of RP as well as in the cpfl1 mouse model of progressive cone dystrophy. Interestingly, inhibition of HDAC I/II activity, using the pan-inhibitor trichostatin A (TSA), prevented photoreceptor cell death in rd1 organotypic retinal explants and in vivo protected cone photoreceptor cells in cpfl1 mice. ${ }^{18,20,22}$

Thus, HDAC inhibitors have therapeutic potential in retinal degeneration. However, the molecular mechanisms underlying the protective effects of HDAC pan-inhibitors are not yet resolved. In particular, the question whether individual isoforms have beneficial effects has not been addressed. In this respect, HDAC6 is of special interest. Among the 18 members of the HDAC family, HDAC6 is a unique class II deacetylase. It possesses two catalytic domains and deacetylates mainly non-histone proteins, such as a-tubulin, cortactin and HSP90 (for recent reviews see refs $21,23,24)$. Furthermore, the redox regulatory protein peroxiredoxin 1 , which is crucial for reducing hydrogen peroxide $\left(\mathrm{H}_{2} \mathrm{O}_{2}\right)$, is a target of HDAC6. ${ }^{25}$ Additionally, HDAC6 is connected to activation of HSP genes ${ }^{26}$ and modulates cellular defense mechanisms. ${ }^{24,25,27}$

In the present study, we used the specific HDAC6 inhibitor tubastatin A (TST) ${ }^{28}$ to evaluate whether inhibition of HDAC6 can provide a protective means against oxidative stress exerted by $\mathrm{H}_{2} \mathrm{O}_{2}$. To better understand the molecular mechanisms elicited by TST on a cellular level, $661 \mathrm{~W}$ cells, representing a mouse cone photoreceptor-like cell line, ${ }^{29}$ were used. To determine whether TST has a therapeutic effect on visual function and retinal morphology in vivo, the dye ucd6 (dying on edge) zebrafish model of inherited blindness, representing a cone dominant visual system, was used. The data show that HDAC6 inhibition plays an important role in neuroprotection.

\section{Results}

HDAC6 is expressed and active in retinal cells. Mousederived cone-like $661 \mathrm{~W}$ cells were used as a cellular model. To investigate whether HDAC6 transcript and protein is present in these cells, and to also verify its constitutive expression in the mouse retina, lysates from wild-type C57BL/6J mouse retinae and $661 \mathrm{~W}$ cells were subjected to immunoblot analysis or reverse transcription polymerase chain reaction (RT-PCR). As shown in Figure 1, HDAC6 protein (Figure 1a) and mRNA (Figure 1b) is detected in retinal extracts and $661 \mathrm{~W}$ cells. The specificity of the antibody against HDAC6 was verified by using a blocking peptide provided by the manufacturer (see Supplementary Information to Figure 1). To study whether HDAC6 is active 
in $661 \mathrm{~W}$ cells and that cells react to its inhibition, cells were incubated with TST for $24 \mathrm{~h}$ and hyperacetylation of $a$-tubulin was assessed by immunoblot procedures and indirect immunofluorescence. Immunoblot analysis pointed to a concentration-dependent effect of TST to increase $a$-tubulin acetylation (ac Tub), which was prominent at a concentration of $10 \mu \mathrm{M}$ (Figure 1c). At even higher concentrations this was more pronounced; however, TST caused a slight cytotoxic effect. Hence, a concentration of $10 \mu \mathrm{M}$ TST was used for subsequent experiments. For indirect immunofluorescence an antibody against ac Tub was used, and to label F-actin Phalloidin-CF594 (red) was applied. In control cells ac Tub was only scarcely present and mainly the microtubule organizing center was prominently stained (Figure 1d). After incubation with $10 \mu \mathrm{M}$ TST microtubules were acetylated throughout the cell cytoplasm and cellular extensions, while the actin network seemed to be unaffected. However, cells appeared more adherent and flattened.

TST protects $661 \mathrm{~W}$ cells against oxidative stress exerted by $\mathbf{H}_{2} \mathbf{O}_{2}$. Since oxidative stress has been connected to retinal degeneration, we tested whether TST is protective and ameliorates the cytotoxic effects of oxidative damage in $661 \mathrm{~W}$ cells. Towards this, $661 \mathrm{~W}$ cells were incubated with $200 \mu \mathrm{M}$ $\mathrm{H}_{2} \mathrm{O}_{2}$ for $6 \mathrm{~h}$ either alone or after a $2 \mathrm{~h}$ pre-incubation with TST $(10 \mu \mathrm{M})$ followed by $200 \mu \mathrm{M} \mathrm{H}_{2} \mathrm{O}_{2}$ for $6 \mathrm{~h}$ in the presence of TST. The microscopical images indicate that after treatment with $\mathrm{H}_{2} \mathrm{O}_{2}$ cells were severely damaged, cellular processes were retracted and less dense (Figure 2). Pretreatment with TST rescued the cells; they kept their healthy morphology and cell density was enhanced. Treatment with TST alone $(8 \mathrm{~h}$, $10 \mu \mathrm{M})$ did not exert any cytotoxic effects. Hence, HDAC6 inhibition by TST exerted protective effects against oxidative stress in $661 \mathrm{~W}$ cells, which was further corroborated by an MTT cell viability assay (see below, Figure 3).

TST elicits a heat-shock response in $661 \mathrm{~W}$ cells and causes the upregulation of HSP25 and HSP70. To investigate further the molecular events underlying the protective effects of TST, we evaluated whether TST promotes the induction of HSPs. Immunoblot analysis revealed that TST led to a significant upregulation of HSP25 (mouse homolog to human HSP27) and only a slight increase of HSP70 after $24 \mathrm{~h}$ in a concentration-dependent manner (Figures $3 a$ and d). After $8 \mathrm{~h}$ of treatment with TST, HSP70 was significantly and HSP25 only slightly enhanced, as compared with the untreated control (Figures $3 \mathrm{~b}$ and $\mathrm{c}$ ). The induction of HSP25 and HSP70 was suppressed in the presence of $\mathrm{H}_{2} \mathrm{O}_{2}$ (Figure 3b).

To test whether TST-mediated HSP induction was accompanied by the activation of heat-shock transcription factor 1 (HSF1) and whether the inhibition of HSF1 activation may enhance the cytotoxic effects of $\mathrm{H}_{2} \mathrm{O}_{2}$, a specific inhibitor of HSF1, namely KRIBB11, was used. ${ }^{30} 661 \mathrm{~W}$ cells were treated with TST (1, 3 and $6 \mathrm{~h}$ ), or with $5 \mu \mathrm{M}$ KRIBB11 for $6.5 \mathrm{~h}$, or preincubated with KRIBB11 for $30 \mathrm{~min}$ followed by TST treatment in the presence of KRIBB11 for further 1, 3 and $6 \mathrm{~h}$. Cell lysates were prepared and subjected to immunoblot analysis using antibodies against HSF1 and as indicated. As seen in Figure 3e after 3-6 h of treatment with TST the migration velocity of HSF1 was slightly decreased and the protein appeared with a higher molecular weight, indicating its phosphorylation and activation. After the combined treatment with KRIBB11 and TST this small shift in migration was still observed, which is due to the fact that KRIBB11 inhibits only the recruitment of the positive transcription elongation factor $\mathrm{b}(\mathrm{p}-\mathrm{TEFb})$ to the $h s p 70$ promoter and not the phosphorylation of HSF1. ${ }^{30}$ After treatment with KRIBB11 and TST the induction of HSP25 and HSP70 was suppressed as compared with the treatment with TST alone (Figure 3b), corroborating its activity.

Next, using an MTT assay, cell viability was assessed. Cells were treated either with TST or KRIBB11 alone, or with $\mathrm{H}_{2} \mathrm{O}_{2}$ alone and in combination with TST and KRIBB11 as described above. While TST and KRIBB11 did not exert cytotoxic effects, treatment with $\mathrm{H}_{2} \mathrm{O}_{2}$ caused a severe decrease in cell viability and less than $30 \%$ of the cells survived (Figure 3f). Preincubation with TST for $2 \mathrm{~h}$ followed by $6 \mathrm{~h}$ of incubation with $200 \mu \mathrm{M} \mathrm{H}_{2} \mathrm{O}_{2}$ in the presence of TST $\left(\mathrm{TST}+\mathrm{H}_{2} \mathrm{O}_{2}\right)$ resulted in a significant enhancement of cell viability $(68 \pm 6 \%)$, when compared with $\mathrm{H}_{2} \mathrm{O}_{2}$ treatment alone. Pre-incubation with KRIBB11 followed by TST and $\mathrm{H}_{2} \mathrm{O}_{2}$ did not affect cell viability as compared with the combined treatment with TST and $\mathrm{H}_{2} \mathrm{O}_{2}$ alone (Figure 3f). Hence, the inhibition of HSF1 and the heatshock response were not sufficient to prevent the protective effects of TST on cell viability, suggesting that other factors might contribute.

The activity of peroxiredoxin 1 is modulated by TST in response to oxidative stress. This prompted us to investigate whether TST in $661 \mathrm{~W}$ cells has an influence on peroxiredoxin 1 (Prx1), which is involved in the reduction of $\mathrm{H}_{2} \mathrm{O}_{2}$ and has been identified as a substrate of HDAC6. ${ }^{25}$ Oxidative stress or $\mathrm{H}_{2} \mathrm{O}_{2}$ can lead to the overoxidation and inactivation of Prx1, which includes the increased formation of inactive overoxidized $\mathrm{PrxSO}_{2 / 3}$ molecules. ${ }^{31} 661 \mathrm{~W}$ cells were incubated with TST $(1,5$ and $10 \mu \mathrm{M})$ alone for $8 \mathrm{~h}$, or with $200 \mu \mathrm{M} \mathrm{H}_{2} \mathrm{O}_{2}$ alone for $6 \mathrm{~h}$, or were preincubated with increasing concentrations of TST for $2 \mathrm{~h}$ followed by $6 \mathrm{~h}$ of incubation with $\mathrm{H}_{2} \mathrm{O}_{2}(200 \mu \mathrm{M})$ in the presence of TST. Cell lysates were subjected to immunoblot analysis using antibodies against $a$-tubulin, acetylated tubulin, Prx1 and $\mathrm{PrxSO}_{2 / 3}$, the overoxidized and thereby inactivated form of Prx1. Anti-Prx1 antibodies recognize Prx1 independent of its oxidation. Figure 4 demonstrates that $\mathrm{H}_{2} \mathrm{O}_{2}$ promoted the overoxidation of Prx1 as indicated by the increased level of $\mathrm{PrxSO}_{2 / 3}$. Pre-incubation with TST in a concentrationdependent manner resulted in decreasing levels of $\mathrm{PrxSO}_{2 / 3}$, while the levels of Prx1 remained at the same level. Thus, TST treatment prevented the inactivation of Prx1, and its preserved activity may exert protective effects.

TST restores visual function and retinal morphology in a zebrafish model of inherited blindness. Zebrafish have been increasingly used as a system to model neurodegeneration and for the study of human eye disorders, since it has similarities to the mammalian nervous system, and has emerged as a vertebrate model organism to combine in vitro and in vivo assays. ${ }^{32,33}$ Previous data confirm that in zebrafish, hdac6 is expressed in the larval eye during maturation of visual function, ${ }^{19}$ and specifically in cone photoreceptors as 

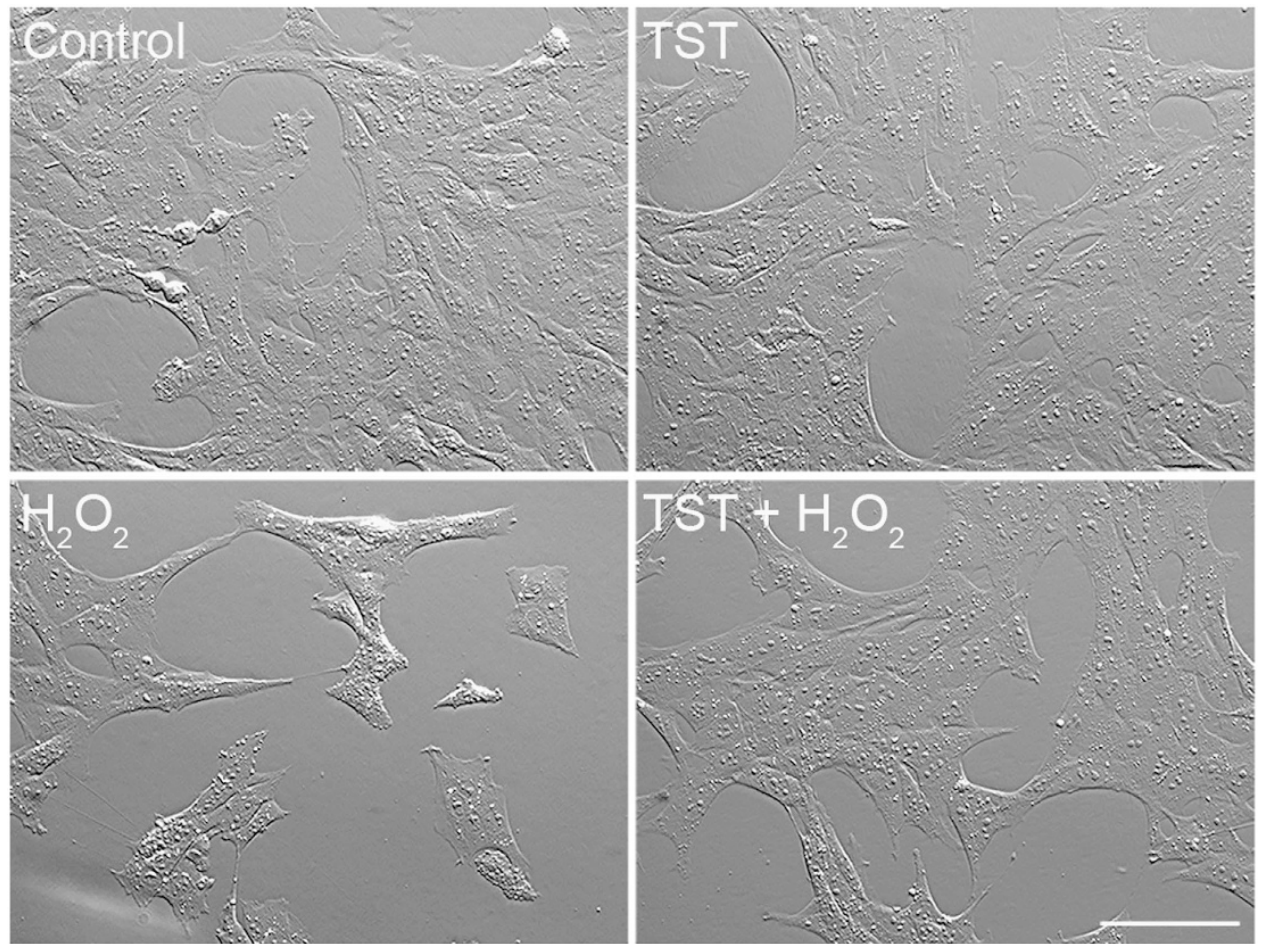

Figure 2 Pre-incubation with tubastatin A protects $661 \mathrm{~W}$ cells against oxidative stress. Hoffmann modulation contrast images are shown. $661 \mathrm{~W}$ cells were treated with $10 \mu \mathrm{M}$ tubastatin A (TST) for $8 \mathrm{~h}$, with $200 \mu \mathrm{M} \mathrm{H}_{2} \mathrm{O}_{2}$ for $6 \mathrm{~h}$, or were preincubated with $10 \mu \mathrm{M} \mathrm{TST}$ for $2 \mathrm{~h}$ followed by incubation with $\mathrm{H}_{2} \mathrm{O}_{2}$ for $6 \mathrm{~h}$. Co, untreated control $(n=5)$. Scale bar: $100 \mu \mathrm{m}$
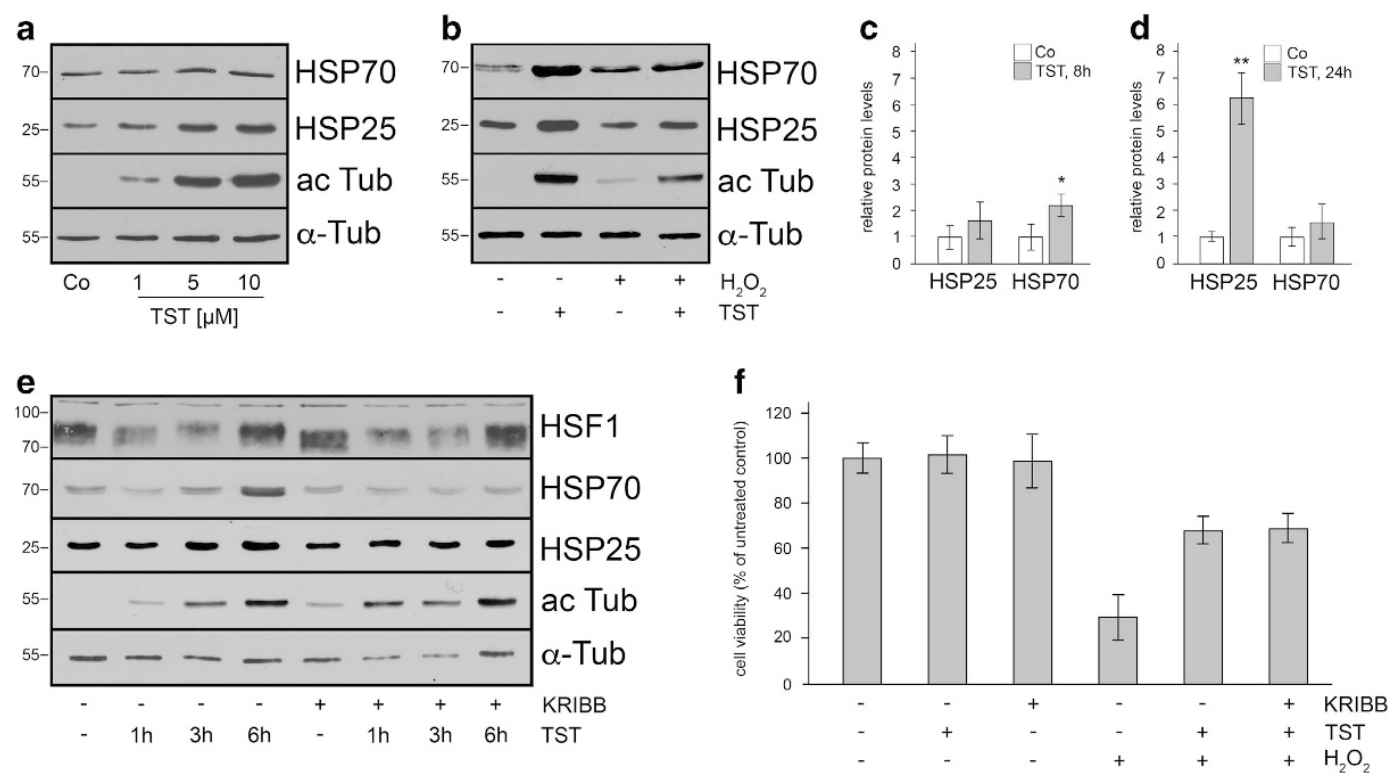

Figure 3 Tubastatin A induces heat-shock protein expression by activating heat-shock factor $1.661 \mathrm{~W}$ cells were treated with 1,5 and $10 \mu \mathrm{M}$ of tubastatin $\mathrm{A}$ (TST) for $24 \mathrm{~h}$ (a), or in (b) with $10 \mu \mathrm{M}$ TST for $8 \mathrm{~h}$, or with $200 \mu \mathrm{M} \mathrm{H}_{2} \mathrm{O}_{2}$ for $6 \mathrm{~h}$ or were preincubated with $10 \mu \mathrm{M} \mathrm{TST}$ for $2 \mathrm{~h}$ followed by incubation with $200 \mu \mathrm{M} \mathrm{H} \mathrm{H}_{2}$ for $6 \mathrm{~h}$. ac Tub, acetylated tubulin. $\alpha$-Tub, $\alpha$-tubulin. Co, untreated control. Quantitative evaluation of immunoblot analysis revealed a significant increase in heat-shock protein (HSP) 70 level after $8 \mathrm{~h}$ (c), while HSP25 was significantly enhanced after $24 \mathrm{~h}(\mathrm{~d}) ; n=4$. (e) Heat-shock factor 1 (HSF1) activity was investigated using immunoblot analysis of $661 \mathrm{~W}$ cell extracts that were treated $10 \mu \mathrm{M} \mathrm{TST}$ for 1,3 and $6 \mathrm{~h}$, or with $5 \mu \mathrm{M}$ KRIBB11 (KR) for $6.5 \mathrm{~h}$ alone, or preincubated with $5 \mu \mathrm{M} \mathrm{KR}$ for $30 \mathrm{~min}$, followed by incubation with $10 \mu \mathrm{M} \mathrm{TST}$ for $1-6 \mathrm{~h}$. (f) Cell viability MTT assay. Cells were treated as indicated. TST $(10 \mu \mathrm{M})$ for $8 \mathrm{~h}$ or $\mathrm{KR}(5 \mu \mathrm{M})$ for $8.5 \mathrm{~h}$ did not influence $661 \mathrm{~W}$ cell number. $\mathrm{H}_{2} \mathrm{O}_{2}(200 \mu \mathrm{M})$ for $6 \mathrm{~h}$ led to a strong decrease in cell viability, which was enhanced by pre-incubation with TST for $2 \mathrm{~h}\left(\mathrm{TST}+\mathrm{H}_{2} \mathrm{O}_{2}\right)$. Pre-incubation with $\mathrm{KR}$ for 30 min followed by incubation with TST for $2 \mathrm{~h}$ followed by treatment with $\mathrm{H}_{2} \mathrm{O}_{2}$ for $6 \mathrm{~h}\left(\mathrm{KR}+\mathrm{TST}+\mathrm{H}_{2} \mathrm{O}_{2}\right)$ did not diminish the protective effect of TST. Experiments were carried out three times with similar results. Data represent the mean \pm S.D. of one representative experiment with eight replicates and are expressed as the percent of the untreated control, which was set at $100 \%$ 
a

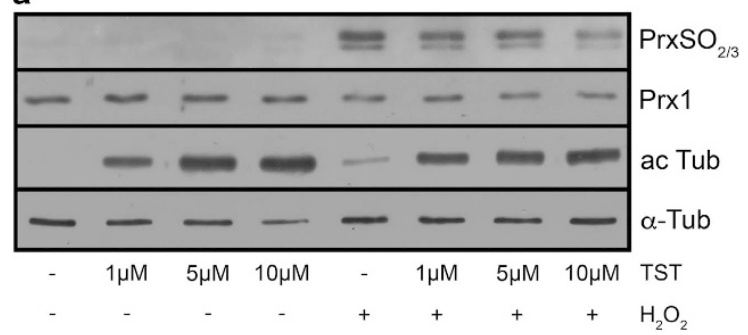

b

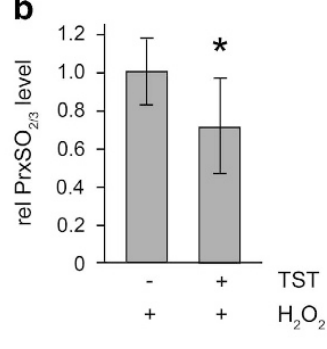

Figure 4 Pre-incubation with tubastatin A regulates the activity of peroxiredoxin 1.661W cells were treated with tubastatin $\mathrm{A}(\mathrm{TST})$ for $8 \mathrm{~h}$ as indicated, or with $\mathrm{H}_{2} \mathrm{O}_{2}(200 \mu \mathrm{M})$ for $6 \mathrm{~h}$, and they were preincubated with 1,5 and $10 \mu \mathrm{M}$ TST for $2 \mathrm{~h}$ followed by incubation with $\mathrm{H}_{2} \mathrm{O}_{2}$ for $6 \mathrm{~h}\left(\mathrm{TST}_{+} \mathrm{H}_{2} \mathrm{O}_{2}\right)$. (a) Immunoblot analysis of cell extracts revealed an $\mathrm{H}_{2} \mathrm{O}_{2}$ induced increase in the level of $\mathrm{PrxSO}_{2 / 3}$, the inactivated form of peroxiredoxin 1 (Prx1), which was significantly reduced by pre-incubation with $10 \mu \mathrm{M}$ TST, as shown by quantitative evaluation of the immunoblot (b). ac Tub, acetylated $\alpha$-tubulin; $\alpha$-Tub, $\alpha$-tubulin. $n=4$

determined by microarray analysis of cone-enriched transcripts from adult zebrafish. ${ }^{34}$ The data are deposited in the $\mathrm{NCBI}$ Gene Expression Omnibus (GEO) database, under accession number GSE86155. Furthermore, in a recent study Pinho et al. ${ }^{35}$ have demonstrated that zebrafish HDAC6 shows high sequence identity with the mammalian homolog at its deacetylase active site. In their study the effects of HDAC inhibitors on a zebrafish model of Parkinson's disease were evaluated. In this model TST increased the levels of acetylated a-tubulin, could not repair 1-methyl-4-phenyl-1,2,3,6-tetrahydropyridine $\left(\mathrm{MPP}^{+}\right)$-induced locomotor impairments but could rescue metabolic activity in whole larvae. ${ }^{35}$

To determine the effect of TST on visual impairment in vivo we utilized the $d y e^{u c d 6}$ zebrafish model of inherited blindness, identified in a forward genetics screen for visual function mutants and characterized by defects in visual behavior and retinal morphology. ${ }^{36}$ First, the effect of TST on dye larvae was analyzed by immunoblot procedure. dye larvae were treated with $100 \mu \mathrm{M}$ TST from 3 to 5 days post fertilization (dpf), larval eyes (50 per each condition) were collected and lysates were subjected to immunoblot analysis. The results show that in vivo TST treatment resulted in an increase of acetylated a-tubulin when compared with $a$-tubulin, suggesting that TST successfully inhibits HDAC6 in dye zebrafish (Figure 5a). Next, visual behavior and retinal morphology was assessed. TST induced a 16.42-fold increase in eye saccades, as measured by the optokinetic response (OKR) assay, when compared with vehicle ( $0.1 \%$ DMSO)-treated control dye larvae (Figure 5b). The visualmotor response (VMR) assay quantifies locomotor activity in direct response to changes in light conditions. In response to $100 \mu \mathrm{M}$ TST treatment, dye larvae showed a 2.52- or 2.07-fold increase in the MAX OFF or MAX ON VMR, respectively, compared with vehicle $(0.1 \%$ DMSO)-treated control dye larvae (Figure 5c). In agreement, TST treatment improved retinal morphology in dye as evidenced by a $77.94 \%$ reduction in the number of dying cells with pyknotic nuclei (red boxes in Figures $5 \mathrm{~d}$ and $\mathrm{g}$, insets e and $h$, quantification $j$ ) in the peripheral retina or ciliary marginal zone (CMZ) and a qualitative improvement in the appearance of photoreceptors (Figures $5 f$ and i). In summary, TST treatment improved two cone photoreceptor-mediated visual behaviors in a zebrafish model of inherited retinal degeneration.

\section{Discussion}

The tubulin deacetylase HDAC6 is considered as a stress surveillance factor, is a key player in neurodegenerative diseases and a potential target for neuroprotection and regeneration. It is involved in a variety of cellular events, including proteasome dysfunction, cell adhesion regulation, heat-shock responses and redox regulation. ${ }^{21,23,24,37}$ The overexpression of HDAC6 has been connected to neurodegenerative disorders, and its specific suppression may provide protection. ${ }^{38,39}$ Here we show that HDAC6 is constitutively expressed in the murine retina and may play a role in retinal diseases, which involve oxidative damage and photoreceptor cell death. Using cone-like $661 \mathrm{~W}$ cells our data demonstrate that in response to oxidative stress and HDAC6 inhibition by the specific inhibitor TST, cell survival was promoted and the levels of HSP25 and HSP70 were elevated. Furthermore, TST influenced the redox regulatory protein Prx1, which is a target of HDAC6 and displays antioxidant capacity. ${ }^{13,40}$ Also, in the dye zebrafish model of inherited sight loss we demonstrate that TST was sufficient to rescue cone-mediated visual function and improve retinal morphology.

Previous studies using mouse models of RP and cone dystrophies have implicated that pan-inhibition of HDACs (class I and II) prevented photoreceptor cell death. ${ }^{18,20}$ However, general HDAC inhibitors lead to the deacetylation of histones and thus influence gene transcription. Additionally, they increase the acetylation of many non-histone proteins. ${ }^{41,42}$ Hence, the finding that HDAC6 in the retina is involved in neuroprotection, and that its specific inhibition has beneficial effects, opens up new therapeutic possibilities using isoform-specific inhibitors. HDAC6 does not act on histones and its major substrate is $a$-tubulin. Acetylated $a$-tubulin occurs on polymerized microtubules (MT) and affects MT dynamics and stability by slowing down the rate of MT growth and shrinkage. ${ }^{43}$ Furthermore, $a$-tubulin acetylation has been demonstrated to be involved in cell adhesion processes. In this respect it was shown that hypoacetylation caused a reduction in cell to substrate adhesion, ${ }^{44}$ and that a failure to deacetylate $a$-tubulin after HDAC6 inhibition resulted in increased cell adhesion and a decrease in cell motility. ${ }^{45}$ Hence, a decrease in MT dynamics after HDAC6 inhibition in cells may promote cell adhesion properties, which might additionally contribute to the preserved cell morphology and cell survival mechanisms, 
a

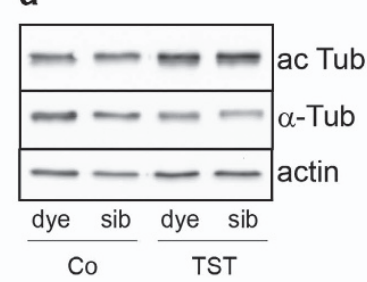

b

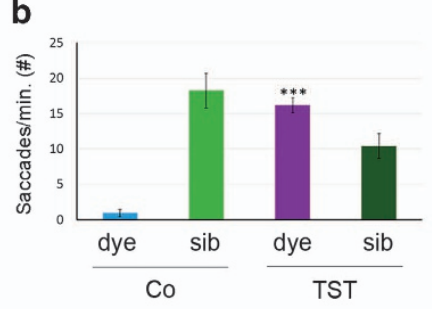

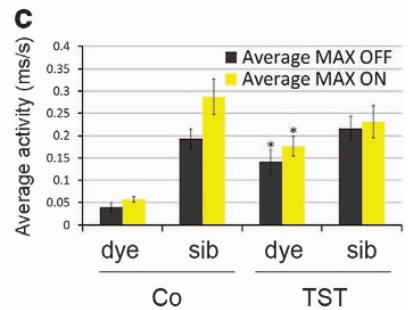
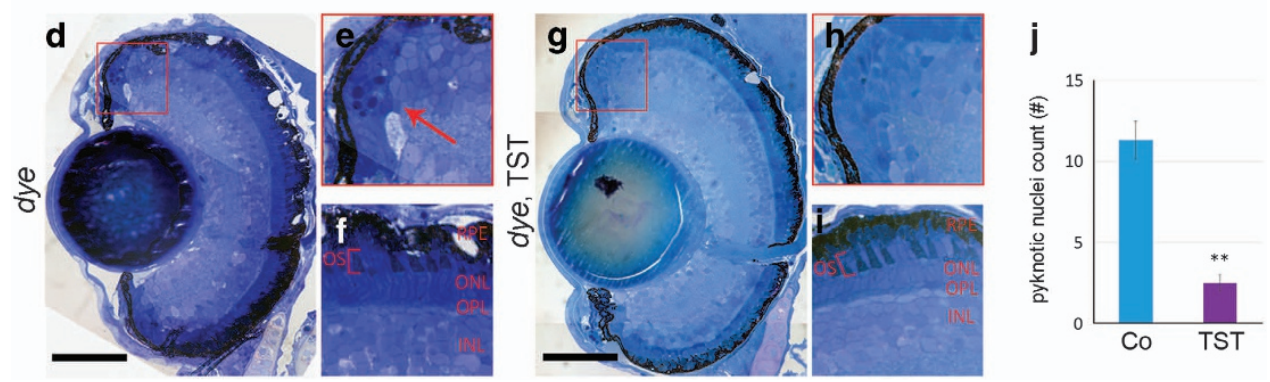

Figure 5 Tubastatin A treatment rescues visual function and retinal morphology defects in the dye zebrafish model of inherited blindness. (a) Dye mutants and siblings were treated with $100 \mu \mathrm{M}$ tubastatin A (TST) from 3 to $5 \mathrm{dpf}$, lysates were prepared from 50 larval eyes each and subjected to immunoblot analysis using antibodies against $\alpha$-tubulin $(\alpha$-Tub), acetylated $\alpha$-tubulin (ac Tub) and actin as a loading control, $n=3$. (b) dye mutants treated with TST revealed significantly improved OKR when compared with vehicle $(0.1 \%$ DMSO)-treated mutants, error bars show standard error of the mean. (c) Summary of VMR activities. Treatment with $100 \mu \mathrm{M}$ TST significantly improves the MAX OFF (black bars) and MAX ON (yellow bars) activities in dye mutants. For visual function data, $N=12$ (number of larvae per replicate), $n=3$ (number of replicates), error bars show standard error of the mean. (d-i) Light micrographs of retinal sections derived from TST ( $\mathbf{g}-\mathbf{i})$ and vehicle-treated dye larvae (d-f). Treatment with $100 \mu \mathrm{M}$ TST reduces the number of dying cells in the ciliary marginal zone (red square in $\mathbf{g}$ and $\mathbf{h}$ ) indicated by the presence of pyknotic nuclei compared with control larvae (red square in $\mathbf{d}$, red arrow in e), scale bars represent $100 \mu \mathrm{m}$. The number of pyknotic nuclei present in multiple sections through the central retina is also reduced (bar chart in j). Photoreceptor outer segment length is marginally improved following TST treatment (i) compared with controls (f), $n=5$. Statistical analyses were performed using a multiple comparison Student's $t$ test with unequal variances comparing dye, $0.1 \%$ DMSO groups to TST-treated larvae, ${ }^{* \star *} P<0.001,{ }^{* *} P<0.01{ }^{*} P<0.05$

as observed in $661 \mathrm{~W}$ cells in the present study. In this context it is of interest to note that a delay in developmental migration or a misplacement of cone photoreceptors is a common feature of retinal degenerative diseases, and that HDAC inhibition by the pan-inhibitor Trichostatin A improved cone migration in a mouse model of inherited primary cone degeneration. ${ }^{20}$

As mentioned above, HDAC6 is involved in a heat-shock response, and HSP90 was identified as its substrate. HSP90 is a molecular chaperone that either stabilizes or promotes the degradation of its client proteins, depending on its acetylation status, which is mediated by acetyltransferase p300 and HDAC6. ${ }^{46,47}$ Hyperacetylation of HSP90, for example, due to HDAC6 inhibition, decreases its affinity for ATP, impairs its chaperone function and favors client degradation. ${ }^{46}$ Furthermore, inhibition of HSP90 exerts neuroprotective effects by upregulation of HSPs in retinal degenerative disorders that are associated with defects in proteolytic systems. ${ }^{15,48}$ Here we show that treatment of $661 \mathrm{~W}$ cells with TST caused an increase in HSP70 and HSP25 by activation of HSF1. HSF1 activity is essential for the expression of many HSPs, including HSP25 and HSP70. In unstressed cells HSF1 is present in a repressive complex involving HDAC6, p97/VCP and HSP90. In response to stress the complex dissociates, HSF1 is activated and translocates to the nucleus where it binds to promoter regions of heat-shock genes triggering their expression. ${ }^{27}$ Especially HSP25 and HSP70 exert important roles in the retina by protecting cells against oxidative stress and even retinal degeneration. ${ }^{16,17}$ Incubation of $661 \mathrm{~W}$ cells with KRIBB11, a specific inhibitor of HSF1 activation, repressed the induction of HSP70 and HSP25 under the condition of oxidative stress. However, this did not attenuate the protective effect of TST against $\mathrm{H}_{2} \mathrm{O}_{2}$-induced cytotoxicity as determined by an MTT cell viability assay. This points to the conclusion that the beneficial effects exerted by these HSPs are not sufficient to prevent cell damage in the present settings and other factors contribute.

The data presented in Figure 4 suggest that peroxiredoxin 1 (Prx1) might be involved in the protective action of TST. Prx1 is a member of the peroxiredoxin family, a class of antioxidant proteins that catalyze the reduction of peroxides and protect cells against oxidative stress. ${ }^{40,49}$ The peroxide reducing activity of Prx1 is dependent on post-translational modifications, in particular acetylation, which is mediated by HDAC6. ${ }^{25,49}$ The depletion of HDAC6 activity, either by siRNA-mediated knockdown or inhibition by tubacin, which represents a less specific derivative of $\mathrm{TST}^{28}$ resulted in hyperacetylated Prx1. ${ }^{25}$ Thus, Prx1 is a specific target of HDAC6 and acetylation increases its reducing activity and resistance to superoxidation. Peroxiredoxins have multiple functions, and besides being sensors for redox signals, they are involved in the regulation of diverse cellular processes, including cell growth, metabolism, and cell death and survival. They are upregulated in cancer and inflammatory diseases, and may provide protection in neurodegenerative diseases that are associated with oxidative damage. ${ }^{40}$ The expression of peroxiredoxins in various compartments of the human eye, and their special abundance in the retina and iris, has been reported. Alterations in their expression patterns after pathological UV-B-associated processes and oxidative-type DNA damage was observed. ${ }^{50}$ Furthermore, peroxiredoxins were prominently expressed in the retina and optic nerve of rats, 
and specifically localized in neurons of the INL and cone photoreceptors. ${ }^{51}$ Hence, peroxiredoxins may be crucial in protecting retinal cells and in particular photoreceptors, which are exposed to a high level of ROS, from oxidative stressinduced injuries.

To determine the effect of TST treatment on visual degeneration in vivo the dye zebrafish model of inherited sight loss was utilized. The mutation in dye affects the atp6v0e1 gene, a subunit of the vacuolar ATPase complex. ${ }^{36}$ This complex is involved in phagocytosis and acidification of intracellular organelles including lysosomes. ${ }^{52}$ The mutant is characterized by cell death in the $\mathrm{CMZ}$ and defects in photoreceptor morphology, leading to severely reduced visual function. These defects may be explained by an inability of retinal pigment epithelial cells to degrade discarded photoreceptor outer segments. ${ }^{53}$ As photoreceptor OS accumulate ROS due to high metabolic activity and exposure to light, ${ }^{54}$ an inability to degrade these components may lead to excessive levels of ROS in the retina. Visual function can be readily assayed in larval zebrafish by behavioral assays, ${ }^{55,56}$ and as rod photoreceptor-mediated vision does not develop until later stages, ${ }^{57}$ the responses recorded in this study are mediated by cone photoreceptors. As mentioned previously, class I/II HDAC inhibitors (HDACi) demonstrate neuroprotective and restorative effects on retinal morphology in mouse models of retinal degeneration. ${ }^{20,58}$ While isoform selectivity of $\mathrm{HDAC} i$ is a contentious issue, trichostatin $A$ and scriptaid, two pan- or class I/II selective HDACi have potent inhibitory activity against HDAC6. ${ }^{59}$ Thus, HDAC6 inhibition may have a significant role in the neuroprotective effects of these less selective HDACi. In addition to the likely accumulation of ROS in the retina, this suggests that the protective effect of TST in dye may be mediated via regulation of peroxiredoxin activity.

\section{Materials and Methods}

Materials and antibodies. Cell culture media were obtained from Invitrogen (Grand Island, NY, USA). Tubastatin A hydrochloride (TST) was purchased from Sigma-Aldrich (Munich, Germany), KRIBB11 was from Merck Millipore (Darmstadt, Germany) and $\mathrm{H}_{2} \mathrm{O}_{2}$ from Roth (Karlsruhe, Germany). MTT (1-(4,5-dimethylthiazol-2yl)-3,5-diphenylformazan) was obtained from USB Corporation (Cleveland, OH, USA). For immunoblot analysis the following antibodies were used: mouse monoclonal antibody (mAb) anti- $\alpha$-tubulin (T9026), 1:5000 and mouse mAb anti-acetylated $\alpha$-tubulin (T6793), 1:1000, were from Sigma-Aldrich. Goat pAb anti-HDAC6 (sc-5258), 1:500, was purchased from Santa Cruz (Heidelberg, Germany). Rat mAb anti-HSF1 (ADI-SPA-950), 1:500, was from Enzo Life Sciences (Lörrach, Germany). Rabbit pAb anti-HSP25 (ADI-SPA-801), 1:2000, and rabbit pAb anti-HSP70 (ADI-SPA-812), 1:1000, were both from Enzo Life Sciences. Rabbit pAb anti-peroxiredoxin 1 (ab15571), 1:1000, and rabbit pAb anti-peroxiredoxinSO ${ }_{2 / 3}$ (ab16830), 1:10 000, anti$\alpha$-tubulin (ab76449), 1:2000 dilution for western blot of zebrafish protein lysate, were obtained from Abcam (Cambridge, UK). HRP-conjugated anti-mouse IgG (1:10 000) and anti-rabbit lgG (1:10 000) were from Jackson ImmunoResearch (West Grove, PA, USA). Indirect immunofluorescence on $661 \mathrm{~W}$ cells was performed using mouse mAb anti-acetylated $\alpha$-tubulin (Sigma-Aldrich, T6793), 1:250, secondary antibody goat antimouse Dylight 488 (Thermo Fisher Scientific, Waltham, MA, USA, 35502), PhalloidinCF594 (Biotium, Hayward, CA, USA, 00045), 1:100 and 4',6-diamidino-2-phenylindole dihydrochloride (DAPI) for nuclear staining, $100 \mathrm{ng} / \mathrm{ml}$ (Sigma-Aldrich, D9542).

Animals. For the experiments 3- to 5-months old wild-type C57BL/6J mice (Charles River, Wilmington, MA, USA) were used. Mice were maintained on a $12 / 12 \mathrm{~h}$ light/dark cycle with food and water ad libitum. Mice were handled and killed in accordance with the institutional guidelines for animal welfare at the University of Oldenburg and the laws on animal experimentation issued by the German government (Tierschutzgesetz). Mice were anesthetized with $\mathrm{CO}_{2}$ and killed by cervical dislocation. Eyes were enucleated in physiological phosphate-buffered saline (PBS; pH 7.4) and the cornea, lens and vitreous were removed from the eyecup. For RT-PCR retinas were dissected from the eyecup in RNAse-free conditions and immediately frozen in liquid nitrogen. For immunoblot analysis retinas were homogenized in sample buffer containing $2 \%$ SDS.

All experiments utilizing zebrafish were performed in accordance with approval granted by the UCD Animal Research Ethics Committee. Homozygous dye larvae were obtained from natural spawning of heterozygous adults. Larvae were maintained on a $14 \mathrm{~h}$ light $/ 10 \mathrm{~h}$ dark cycle at $28.5^{\circ} \mathrm{C}$ in embryo medium $(0.137 \mathrm{M}$ $\mathrm{NaCl}, 5.4 \mathrm{mM} \mathrm{KCl}, 5.5 \mathrm{mM} \mathrm{Na}_{2} \mathrm{HPO}_{4}, 0.44 \mathrm{mM} \mathrm{KH}_{2} \mathrm{PO}_{4}, 1.3 \mathrm{mM} \mathrm{CaCl}, 1.0 \mathrm{mM}$ $\mathrm{MgSO}_{4}$ and $4.2 \mathrm{mM} \mathrm{NaHCO}_{3}$, conductivity $1200 \mu \mathrm{s}, \mathrm{pH} 7.2$ ) until 3 days post fertilization (dpf).

Cell culture and treatment. In this study the immortal mouse photoreceptorderived 661W cell line, obtained from Dr. Muayyad Al-Ubaidi (Department of Cell Biology, University of Oklahoma, Health Sciences Centre, Oklahoma City, OK, USA), was used. $661 \mathrm{~W}$ cells were kept in DMEM supplemented with $10 \%$ fetal bovine serum, $2 \mathrm{mM}$ glutamine, $50 \mathrm{U} / \mathrm{ml}$ penicillin and $50 \mu \mathrm{g} / \mathrm{ml}$ streptomycin. Cell morphology was monitored by Hoffman modulation contrast imaging (Olympus IX70/SF8, Tokyo, Japan). To analyze the effect of HDAC6 inhibition, oxidative stress and HSF1 inhibition on protein expression in 661W cells, 350000 cells were seeded on $10 \mathrm{~cm}$ cell culture dishes (TPP, Trasadingen, Switzerland) and allowed to attach and proliferate for $48 \mathrm{~h}$. Cells were incubated with TST, $\mathrm{H}_{2} \mathrm{O}_{2}$ and KRIBB11 as indicated. To evaluate the effect of TST in response to oxidative stress, $661 \mathrm{~W}$ cells were either left untreated or were incubated with 1,5 and $10 \mu \mathrm{M}$ TST for $8 \mathrm{~h}$, with $200 \mu \mathrm{M} \mathrm{H}_{2} \mathrm{O}_{2}$ for $6 \mathrm{~h}$ or preincubated with 1,5 and $10 \mu \mathrm{M}$ TST for $2 \mathrm{~h}$ followed by $200 \mu \mathrm{M} \mathrm{H}_{2} \mathrm{O}_{2}$ for $6 \mathrm{~h}$ in the presence of TST. To study whether TST induces HSF1, $661 \mathrm{~W}$ cells were treated with $10 \mu \mathrm{M}$ TST for 1,3 and $6 \mathrm{~h}$, or with $5 \mu \mathrm{M}$ KRIBB11 for $6.5 \mathrm{~h}$, or preincubated with KRIBB11 for $30 \mathrm{~min}$ followed by TST treatment in the presence of KRIBB11 for further 1, 3 and $6 \mathrm{~h}$. After treatment, cells were washed with PBS and either lysed in sample buffer containing $2 \%$ SDS for immunoblot analysis or subjected to indirect immunofluorescence. TST and KRIBB11 stock solutions were prepared using DMSO. $\mathrm{H}_{2} \mathrm{O}_{2}$ was diluted in aqua bidest before treatment.

Indirect immunofluorescence. $661 \mathrm{~W}$ cells were cultured on glass coverslips (Fisher Scientific, Schwerte, Germany) for $48 \mathrm{~h}$ in DMEM/10\% FBS/P/ $\mathrm{S}$ and incubated with TST for $24 \mathrm{~h}$. After washing with PBS, cells were fixed with $3 \%$ paraformaldehyde (PFA) for $15 \mathrm{~min}$ and permeabilized with $0.1 \%$ Triton-X-100 for 20 min. After another washing step, unspecific binding sites were blocked with $5 \%$ BSA for $30 \mathrm{~min}$. Cells were incubated with anti-acetylated $\alpha$-tubulin antibody, overnight at $4{ }^{\circ} \mathrm{C}$ and washed three times with PBS. Incubation with secondary antibody and Phalloidin-CF594 was conducted for $1 \mathrm{~h}$ at room temperature in the dark, cells were washed and mounted. Nuclei were stained by 4',6-diamidino-2phenylindole (DAPI; $1.5 \mu \mathrm{g} / \mathrm{ml}$ ) included in the mounting medium (Vectashield; Vector Laboratories, Burlingame, CA, USA)

Fluorescent image acquisition. Fluorescent staining of $661 \mathrm{~W}$ cells was analyzed using a Leica TCS SL confocal microscope (SP8, Wetzlar, Germany). Scanning was performed with an oil-immersion $\times 63 /$ NA1.40 objective. Confocal stacks were processed with ImageJ $(\mathrm{NIH}$, Bethesda, MD, USA). Brightness and contrast were adjusted using Adobe Photoshop CC 2015 (San Jose, CA, USA).

Immunoblot analysis. $661 \mathrm{~W}$ cells, mouse and zebrafish retina lysates were boiled for $10 \mathrm{~min}$ and protein concentrations were determined according to Neuhoff et al. ${ }^{60}$ For immunoblotting, total cellular extracts $(10-40 \mu \mathrm{g}$ protein per lane) were separated by one-dimensional SDS polyacrylamide gel electrophoresis (SDSPAGE) using 7.5 and $10 \%$ polyacrylamide gels and transferred onto nitrocellulose membranes (Whatman, Dassel, Germany; $0.2 \mu \mathrm{m}$ ). Unspecific binding sites were blocked with $5 \%$ powdered milk in TBS (20 mM Tris, $137 \mathrm{mM} \mathrm{NaCl}, \mathrm{pH} 7.5)$, for peroxiredoxin antibodies blocking was performed using RotiBlock (Carl Roth). Blots were incubated with primary antibodies overnight at $4^{\circ} \mathrm{C}$. After washing with TBS with $0.1 \% \mathrm{v} / \mathrm{v}$ Tween 20 (TBS-T), incubation with HRP-conjugated anti-mouse $(1: 10000)$ or anti-rabbit $(1: 10000)$ antibody was carried out for $1 \mathrm{~h}$ at RT. Membranes were washed again several times with TBS-T and signals were visualized by the enhanced chemiluminescence procedure as described by the manufacturer (Thermo Scientific, Rockford, IL, USA).

RNA extraction and RT-PCR. RNA from C57BL/6J retina lysates was isolated using a RNA preparation kit (NucleoSpin RNA XS, Macherey Nagel) 
following the manufacturer's instruction. Additional DNAse digestion was performed with DNasel Amp Grade (Invitrogen) using $1 \mu \mathrm{g}$ of RNA. Complementary DNA (cDNA) was synthesized for $50 \mathrm{~min}$ at $50^{\circ} \mathrm{C}$ in a final volume of $20 \mu \mathrm{l}$. Each sample contained $25 \mu \mathrm{g} / \mathrm{ml}$ oligo-(dT) 15 primer and $25 \mu \mathrm{g} / \mathrm{ml}$ random primer (Promega, Madison, WI, USA), $0.5 \mathrm{mM}$ dNTP (Carl Roth). After primer annealing (5 min at $65^{\circ} \mathrm{C}$ ), samples were cooled on ice prior to the addition of $2 \mathrm{U} / \mu \mathrm{l}$ RiboLock (Thermo Fisher Scientific), $1 \times$ first-strand buffer, $5 \mathrm{mM}$ DTT and $10 \mathrm{U} / \mu \mathrm{l}$ of SuperScriptlll reverse transcriptase (Invitrogen, Carlsbad, CA, USA). RNA from untreated 661W cells was extracted using the RNeasy Mini Kit according to the manufacturer's protocol for animal cells (Qiagen, Hilden, Germany). One microgram of RNA was used for reverse transcription in a final volume of $25 \mu \mathrm{l}$. First-strand synthesis was performed with $2 \mathrm{mM}$ of each dNTP, $0.6 \mu \mathrm{M}$ each of oligo-(dT)18 (Fermentas, Fisher Scientific, Schwerte, Germany) and random hexamer primer (Promega), $4 \mu \mathrm{l}$ of $5 \mathrm{x}$ M-MLV-reaction buffer, $40 \mathrm{U}$ of recombinant RNasin ribonuclear inhibitor and $200 \mathrm{U}$ of M-MLV reverse transcriptase (Promega). After a denaturation step $\left(70^{\circ} \mathrm{C}\right.$ for $5 \mathrm{~min}$ ) and incubation at $37^{\circ} \mathrm{C}$ for $1 \mathrm{~h}, 40 \mu \mathrm{l}$ of DEPC-treated water was added to the reaction mixture. One microliter of CDNA was used for PCR analysis.

PCR reactions were carried in a volume of $25 \mu \mathrm{l}$ containing DreamTaq reaction buffer, $0.025 \mathrm{U} / \mu \mathrm{l}$ DreamTaq DNA polymerase, $0.2 \mathrm{mM}$ of each dNTP (Thermo Fisher Scientific) and $0.4 \mu \mathrm{M}$ of each primer: HDAC6 (intron spanning), $5^{\prime}$-CTGCAGT CGCTATGTCAATG-3' and 5'-GTCCTCCCCAAACTTGTTCT-3' (Biomol, Hamburg, Germany) and GAPDH, 5'-TGGCAAAGTGGAGATTGTTG-3' and 5'- ACTGTGGTCA TGAGCCCTTC-3' (synthesized by Invitrogen, Darmstadt, Germany). For HDAC6 detection 27 cycles, consisting of $30 \mathrm{~s}$ denaturation at $94^{\circ} \mathrm{C}, 30 \mathrm{~s}$ primer annealing at $60^{\circ} \mathrm{C}$ and $45 \mathrm{~s}$ elongation at $72^{\circ} \mathrm{C}$, were run in a BiometraThermocycler. GAPDH was detected by performing 24 cycles, consisting of $30 \mathrm{~s}$ denaturation at $94^{\circ} \mathrm{C}, 30 \mathrm{~s}$ primer annealing at $62{ }^{\circ} \mathrm{C}$ and $45 \mathrm{~s}$ elongation at $72{ }^{\circ} \mathrm{C}$. After a final extension for 4 min at $72{ }^{\circ} \mathrm{C}$ samples were stored at $4^{\circ} \mathrm{C}$. Eight microliters were used for analysis by agarose gel electrophoresis.

MTT assay. To assess the influence of KRIBB11 on the cell viability of TST- and $\mathrm{H}_{2} \mathrm{O}_{2}$-treated $661 \mathrm{~W}$ cells, the colorimetric MTT (tetrazolium) assay was carried out. 661W cells were plated on 96-microwell cell culture plates (4500 cells/well) and allowed to adhere and proliferate for $24 \mathrm{~h}$ in $100 \mu \mathrm{l}$ DMEM/10\% FBS/P/S. Growth medium was replaced with $100 \mu$ of fresh medium only or medium supplemented with $10 \mu \mathrm{M}$ TST, $5 \mu \mathrm{M}$ KRIBB11 and $200 \mu \mathrm{M} \mathrm{H}_{2} \mathrm{O}_{2}$, respectively. Cells were incubated with TST for $8 \mathrm{~h}$, with KRIBB11 for $8.5 \mathrm{~h}$ and with $\mathrm{H}_{2} \mathrm{O}_{2}$ for $6 \mathrm{~h}$. Furthermore, cells were preincubated with TST for $2 \mathrm{~h}$ followed by $\mathrm{H}_{2} \mathrm{O}_{2}$ for $6 \mathrm{~h}$ in the presence of TST, or with KRIBB11 for 30 min followed by TST for $2 \mathrm{~h}$ followed by $\mathrm{H}_{2} \mathrm{O}_{2}$ for $6 \mathrm{~h}$ in the presence of KRIBB11 and TST. Ten microliters of MTT solution $(5 \mathrm{mg} / \mathrm{ml}$ in PBS) was added and cells were incubated for $2 \mathrm{~h}$. Thereafter, $100 \mu \mathrm{l}$ of solubilization solution ( $10 \%$ sodium dodecyl sulfate in $0.01 \mathrm{~mol} / / \mathrm{HCl}$ ) was added and incubated overnight to dissolve the water-insoluble formazan salt. Quantification was carried out using an ELISA reader for measuring absorbance at $595 \mathrm{~nm}$. Data are expressed as the percentage of the untreated control, which was set at $100 \%$ and values represent the mean \pm S.D. of eight microwells of one experiment. Three independent experiments were performed with similar results concerning the protective effect of TST and the influence of KRIBB11. The high variability of $\mathrm{H}_{2} \mathrm{O}_{2}$ cytotoxicity, however, led to the exclusion of these data from statistical analysis. One representative result is depicted in Figure 4.

Larval zebrafish drug treatment. Three dpf dye larvae and controls were placed in embryo medium and incubated with drug dissolved in DMSO, to a final concentration of $100 \mu \mathrm{M}$ TST and $0.1 \%$ DMSO or $0.1 \%$ DMSO alone. Larvae were maintained on a $14 \mathrm{~h} \mathrm{light} / 10 \mathrm{~h}$ dark cycle at $28.5^{\circ} \mathrm{C}$ until $5 \mathrm{dpf}$ when removed from drug solution and used for immunoblotting, histology and visual function assays.

For immunoblot analysis $5 \mathrm{dpf}$ TST or $0.1 \%$ DMSO treated dye larvae were killed via anesthetic overdose (4\% Tricaine), transferred to a protein extraction buffer (50 mM HEPES/KOH pH 7.2, 5 mM EGTA, 10 mM KCl, 2 mM MgCl2, 0.2\% SDS) and enucleated. Fifty larval eyes for each condition were collected, were sonicated at $5 \%$ amplitude for $10 \mathrm{~s}$ using a Soni-prep 150 (Sanyo) in $50 \mu \mathrm{l}$ extraction buffer and sample buffer containing SDS was added. Cell lysates were subjected to immunoblot analysis as described above.

For histology $5 \mathrm{dpf}$ larvae were killed with a lethal dose of tricaine. Whole larvae were fixed in 4\% PFA and 2.5\% glutaraldehyde in 0.1M Sorensons's buffer $(\mathrm{pH} 7.3)$ overnight at $4{ }^{\circ} \mathrm{C}$. Samples were post-fixed using $1 \%$ osmium tetraoxide, dehydrated in ascending concentrations of ethanol and transferred to descending propylene oxide:Epon 812 resin mixtures before embedding in EPON resin alone. Embedded samples were polymerized overnight at $60^{\circ} \mathrm{C}$. One micrometer sections were prepared using a Leica EM UC6 microtome and glass knife, mounted on glass slides and stained with toluidine blue. Sections were coverslipped and imaged using a Leica DMLB bright field illumination microscope and Leica DFC 480 camera $\times 100$ objective. Whole-eye images are composites from at least two images; insets are digitally zoomed images of regions of interest. The number of dying cells were quantified by counting the number of pyknotic nuclei present in multiple sections in the central retina (10 $\mu \mathrm{m}$ distance apart).

OKR assay. Individual 5 dpf larva were immobilized in a Petri dish using $9 \%$ methylcellulose solution. The Petri dish was placed inside a circular $18^{\circ}$ repeating black and white striped pattern at $99 \%$ contrast. $^{55}$ The pattern was rotated around the immobilized larva at 18 revolutions per minute for $30 \mathrm{~s}$ in both clockwise and anti-clockwise directions, and the number of saccadic eye movements produced by the larva per minute was recorded.

VMR assay. The VMR assay quantifies changes in locomotor behavior of larvae in response to transitions in light conditions. Twelve larvae per treatment group were transferred in $600 \mu$ lembryo medium to separate wells of a transparent $650 \mu \mathrm{l} 96$ square-well plate. The plate was transferred to the Zebrabox recording chamber (Viewpoint Life Sciences, Montreal, QC, Canada), and larvae were allowed to acclimate to light conditions for $1 \mathrm{~h}$ before recording is initiated. During the $1 \mathrm{~h} 40 \mathrm{~min}$ recording period there is a $20 \mathrm{~min}$ period in light, followed immediately by $20 \mathrm{~min}$ in the dark, these cycles were repeated until the recording period was complete. Detection settings and analysis were carried out as previously described. ${ }^{61}$ Average MAX ON and average MAX OFF responses were determined by the average maximum locomotor activity (measured in $\mathrm{ms} / \mathrm{s}$ ) per treatment group in the $5 \mathrm{~s}$ period after a transition to light or dark conditions.

Statistics. All experiments were carried out at least three times with similar results, unless stated otherwise. Quantitative evaluation of immunoblots was performed by densitometric analysis using ImageJ. For HSP25 and HSP70 analysis protein levels were normalized to actin and expressed as relative to the control, which was set as 1 . For $\mathrm{PrxSO}_{2 / 3}$ quantification values were normalized to $\mathrm{Prx} 1$ protein bands and expressed relative to $\mathrm{H}_{2} \mathrm{O}_{2}$-treated cells, set as 1 . Statistical significance was determined using a two-sided paired $t$-test (IBM SPSS Statistics, Version 24). Normal distribution of differences was tested (Shapiro Wilk test) and significance levels were $P<0.05\left(^{*}\right)$, $\left.P<0.01{ }^{(*}\right)$ and $\left.P<0.001{ }^{(* *}\right)$. For zebrafish visual function and retinal morphology data were analyzed using an independent two-sample $t$-test with unequal variances.

\section{Conflict of Interest}

The authors declare no conflict of interest.

Acknowledgements. This work was supported by the DFG grant GRK 1885/1. This publication is independent research partly funded by Fighting Blindness and the Health Research Board in Ireland under Grant No: MRCG/2014/3. Any opinions, findings, conclusions or recommendations expressed are those of the author(s) and not necessarily those of Fighting Blindness or the HRB. CRL and JL thank Angelika Spanjer, Irina Fomins and Bettina Kewitz for excellent technical assistance and Dr. Olaf Goldbaum for helpful discussions. BK and CD thank Ms. Julie Slade for assistance with zebrafish visual function assays. UCD Conway Institute Imaging Core for zebrafish histology preparation and imaging.

\section{Publisher's Note}

Springer Nature remains neutral with regard to jurisdictional claims in published maps and institutional affiliations.

1. Guadagni V, Novelli E, Piano I, Gargini C, Strettoi E. Pharmacological approaches to retinitis pigmentosa: a laboratory perspective. Prog Retin Eye Res 2015; 48: 62-81.

2. Roosing S, Thiadens AA, Hoyng CB, Klaver CC, den Hollander Al, Cremers FP. Causes and consequences of inherited cone disorders. Prog Retin Eye Res 2014; 42: 1-26.

3. Halliwell B. Oxidative stress and neurodegeneration: where are we now? $J$ Neurochem 2006; 97: 1634-1658.

4. Cuenca N, Fernandez-Sanchez L, Campello L, Maneu V, De la Villa P, Lax P et al. Cellular responses following retinal injuries and therapeutic approaches for neurodegenerative diseases. Prog Retin Eye Res 2014; 43: 17-75.

5. Narayan DS, Wood JP, Chidlow G, Casson RJ. A review of the mechanisms of cone degeneration in retinitis pigmentosa. Acta Ophthalmol 2016; 94: 748-754.

6. Martinez-Fernandez de la Camara C, Salom D, Sequedo MD, Hervas D, Marin-Lambies C Aller $E$ et al. Altered antioxidant-oxidant status in the aqueous humor and peripheral blood of patients with retinitis pigmentosa. PLOS ONE 2013; 8: e74223. 
7. Campochiaro PA, Strauss RW, Lu L, Hafiz G, Wolfson Y, Shah SM et al. Is there excess oxidative stress and damage in eyes of patients with retinitis pigmentosa? Antioxid Redox Signal 2015; 23: 643-648.

8. Kang K, Tarchick MJ, Yu X, Beight C, Bu P, Yu M. Carnosic acid slows photoreceptor degeneration in the Pde6b(rd10) mouse model of retinitis pigmentosa. Sci Rep 2016; 6: 22632.

9. Lee SY, Usui S, Zafar AB, Oveson BC, Jo YJ, Lu L et al. N-Acetylcysteine promotes long-term survival of cones in a model of retinitis pigmentosa. J Cell Physiol 2011; 226: 1843-1849.

10. Komeima K, Rogers BS, Campochiaro PA. Antioxidants slow photoreceptor cell death in mouse models of retinitis pigmentosa. J Cell Physiol 2007; 213: 809-815.

11. Richter-Landsberg C. Heat shock proteins: expression and functional roles in nerve cells and glia. In: Richter-Landsberg C. (ed.). Heat Shock Proteins in Neural Cells. Landes Bioscience: New York, 2007, pp 1-12.

12. Stahnke T, Stadelmann C, Netzler A, Bruck W, Richter-Landsberg C. Differential upregulation of heme oxygenase-1 (HSP32) in glial cells after oxidative stress and in demyelinating disorders. J Mol Neurosci 2007; 32: 25-37.

13. Athanasiou D, Aguila M, Bevilacqua D, Novoselov SS, Parfitt DA, Cheetham ME. The cell stress machinery and retinal degeneration. FEBS Lett 2013; 587: 2008-2017.

14. Parfitt DA, Aguila M, McCulley CH, Bevilacqua D, Mendes HF, Athanasiou D et al. The heatshock response co-inducer arimoclomol protects against retinal degeneration in rhodopsin retinitis pigmentosa. Cell Death Dis 2014; 5: e1236.

15. Aguila M, Bevilacqua D, McCulley C, Schwarz N, Athanasiou D, Kanuga N et al. Hsp90 inhibition protects against inherited retinal degeneration. Hum Mol Genet 2014; 23: 2164-2175.

16. Furukawa A, Koriyama Y. A role of heat shock protein 70 in photoreceptor cell death: potential as a novel therapeutic target in retinal degeneration. CNS Neurosci Ther 2016; 22: 7-14.

17. O'Reilly AM, Currie RW, Clarke DB. HspB1 (Hsp 27) expression and neuroprotection in the retina. Mol Neurobiol 2010; 42: 124-132.

18. Sancho-Pelluz J, Alavi MV, Sahaboglu A, Kustermann S, Farinelli P, Azadi S et al. Excessive HDAC activation is critical for neurodegeneration in the rd1 mouse. Cell Death Dis 2010; 1: e24.

19. Daly C, Yin J, Kennedy BN. Histone deacetylase: therapeutic targets in retinal degeneration. Adv Exp medicine Biol 2016; 854: 455-461.

20. Trifunovic D, Arango-Gonzalez B, Comitato A, Barth M, Del Amo EM, Kulkarni M et al. HDAC inhibition in the cpfl1 mouse protects degenerating cone photoreceptors in vivo. Hum Mol Genet 2016; 25: 4462-4472.

21. d'Ydewalle C, Bogaert E, Van Den Bosch L. HDAC6 at the intersection of neuroprotection and neurodegeneration. Traffic 2012; 13: 771-779.

22. Sancho-Pelluz J, Paquet-Durand F. HDAC inhibition prevents Rd1 mouse photoreceptor degeneration. Adv Exp Med Biol 2012; 723: 107-113.

23. Li Y, Shin D, Kwon SH. Histone deacetylase 6 plays a role as a distinct regulator of diverse cellular processes. FEBS J 2013; 280: 775-793.

24. Richter-Landsberg C, Leyk J. Inclusion body formation, macroautophagy, and the role of HDAC6 in neurodegeneration. Acta Neuropathol 2013; 126: 793-807.

25. Parmigiani RB, Xu WS, Venta-Perez G, Erdjument-Bromage $H$, Yaneva M, Tempst $P$ et al. HDAC6 is a specific deacetylase of peroxiredoxins and is involved in redox regulation. Proc Natl Acad Sci USA 2008; 105: 9633-9638.

26. Boyault C, Zhang Y, Fritah S, Caron C, Gilquin B, Kwon SH et al. HDAC6 controls major cell response pathways to cytotoxic accumulation of protein aggregates. Genes Dev 2007; 21: 2172-2181

27. Pernet L, Faure V, Gilquin B, Dufour-Guerin S, Khochbin S, Vourc'h C. HDAC6-ubiquitin interaction controls the duration of HSF1 activation after heat shock. Mol Biol Cell 2014; 25: 4187-4194.

28. Butler KV, Kalin J, Brochier C, Vistoli G, Langley B, Kozikowski AP. Rational design and simple chemistry yield a superior, neuroprotective HDAC6 inhibitor, tubastatin A. J Am Chem Soc 2010; 132: 10842-10846.

29. Tan E, Ding XQ, Saadi A, Agarwal N, Naash MI, Al-Ubaidi MR. Expression of conephotoreceptor-specific antigens in a cell line derived from retinal tumors in transgenic mice. Invest Ophthalmol Vis Sci 2004; 45: 764-768.

30. Yoon YJ, Kim JA, Shin KD, Shin DS, Han YM, Lee YJ et al. KRIBB11 inhibits HSP70 synthesis through inhibition of heat shock factor 1 function by impairing the recruitment of positive transcription elongation factor b to the hsp70 promoter. J Biol Chem 2011; 286: 1737-1747.

31. Rhee SG, Woo HA, Kil IS, Bae SH. Peroxiredoxin functions as a peroxidase and a regulator and sensor of local peroxides. J Biol Chem 2012; 287: 4403-4410.

32. Martin-Jimenez R, Campanella M, Russell C. New zebrafish models of neurodegeneration. Curr Neurol Neurosci Rep 2015; 15: 33.

33. Chhetri J, Jacobson G, Gueven N. Zebrafish-on the move towards ophthalmological research. Eye (London, England) 2014; 28: 367-380.

34. Glaviano A, Smith AJ, Blanco A, McLoughlin S, Cederlund ML, Heffernan T et al. A method for isolation of cone photoreceptors from adult zebrafish retinae. BMC Neurosci 2016; 17: 71

35. Pinho BR, Reis SD, Guedes-Dias P, Leitao-Rocha A, Quintas C, Valentao $P$ et al. Pharmacological modulation of HDAC1 and HDAC6 in vivo in a zebrafish model: therapeutic implications for Parkinson's disease. Pharmacol Res 2016; 103: 328-339.

36. Shine L, Sapetto-Rebow B, Reynolds AL, Alvarez Y, McLoughlin S, Kennedy BN. Retinal progenitor apoptosis and aberrant photoreceptor morphology characterise the dying on edge (Dye) zebrafish mutant. Invest Ophthalmol Vis Sci 2010; 51: 3655.
37. Rivieccio MA, Brochier C, Willis DE, Walker BA, D'Annibale MA, McLaughlin K et al. HDAC6 is a target for protection and regeneration following injury in the nervous system. Proc Natl Acad Sci USA 2009; 106: 19599-19604.

38. Ding H, Dolan PJ, Johnson GV. Histone deacetylase 6 interacts with the microtubuleassociated protein tau. J Neurochem 2008; 106: 2119-2130.

39. d'Ydewalle C, Krishnan J, Chiheb DM, Van Damme P, Irobi J, Kozikowski AP et al. HDAC6 inhibitors reverse axonal loss in a mouse model of mutant HSPB1-induced Charcot-MarieTooth disease. Nat Med 2011; 17: 968-974.

40. Park MH, Jo M, Kim YR, Lee CK, Hong JT. Roles of peroxiredoxins in cancer, neurodegenerative diseases and inflammatory diseases. Pharmacol Ther 2016; 163: 1-23.

41. Kazantsev AG, Thompson LM. Therapeutic application of histone deacetylase inhibitors for central nervous system disorders. Nat Rev Drug Discov 2008; 7: 854-868.

42. Fischer A, Sananbenesi F, Mungenast A, Tsai LH. Targeting the correct HDAC(s) to treat cognitive disorders. Trends Pharmacol Sci 2010; 31: 605-617.

43. Janke C, Bulinski JC. Post-translational regulation of the microtubule cytoskeleton: mechanisms and functions. Nat Rev Mol Cell Biol 2011; 12: 773-786.

44. Aguilar A, Becker L, Tedeschi T, Heller S, Iomini C, Nachury MV. Alpha-tubulin K40 acetylation is required for contact inhibition of proliferation and cell-substrate adhesion. $\mathrm{Mol}$ Biol Cell 2014; 25: 1854-1866.

45. Tran AD, Marmo TP, Salam AA, Che S, Finkelstein E, Kabarriti R et al. HDAC6 deacetylation of tubulin modulates dynamics of cellular adhesions. J Cell Sci 2007; 120(Pt 8): 1469-1479.

46. Mollapour M, Neckers L. Post-translational modifications of Hsp90 and their contributions to chaperone regulation. Biochim Biophys Acta 2012; 1823: 648-655.

47. Rao R, Fiskus W, Yang Y, Lee P, Joshi R, Fernandez P et al. HDAC6 inhibition enhances 17AAG-mediated abrogation of hsp90 chaperone function in human leukemia cells. Blood 2008; 112: 1886-1893.

48. Aguila M, Cheetham ME. Hsp90 as a potential therapeutic target in retinal disease. Adv Exp Med Biol 2016; 854: 161-167.

49. Ledgerwood EC, Marshall JW, Weijman JF. The role of peroxiredoxin 1 in redox sensing and transducing. Archiv Biochem Biophys 2017; 617: 60-67.

50. Klebe S, Callahan T, Power JH. Peroxiredoxin I and II in human eyes: cellular distribution and association with pterygium and DNA damage. J Histochem Cytochem 2014; 62: 85-96.

51. Chidlow G, Wood JP, Knoops B, Casson RJ. Expression and distribution of peroxiredoxins in the retina and optic nerve. Brain Struct Funct 2016; 221: 3903-3925.

52. Forgac M. Structure and properties of the vacuolar (H+)-ATPases. J Biol Chem 1999; 274 12951-12954.

53. Nuckels RJ, Ng A, Darland T, Gross JM. The vacuolar-ATPase complex regulates retinoblast proliferation and survival, photoreceptor morphogenesis, and pigmentation in the zebrafish eye. Invest Ophthalmol Vis Sci 2009; 50: 893-905.

54. Nita M, Grzybowski A. The role of the reactive oxygen species and oxidative stress in the pathomechanism of the age-related ocular diseases and other pathologies of the anterior and posterior eye segments in adults. Oxid Med Cell Longev 2016; 2016: 3164734

55. Brockerhoff SE. Measuring the optokinetic response of zebrafish larvae. Nat Protoc 2006; 1 : 2448-2451.

56. Emran F, Rihel J, Dowling JE. A behavioral assay to measure responsiveness of zebrafish to changes in light intensities. J Vis Exp 2008; 20: 923.

57. Bilotta J, Saszik S, Sutherland SE. Rod contributions to the electroretinogram of the darkadapted developing zebrafish. Dev Dyn 2001; 222: 564-570.

58. Sancho-Pelluz J, Alavi MV, Sahaboglu A, Kustermann S, Farinelli P, Azadi S et al. Excessive HDAC activation is critical for neurodegeneration in the rd1 mouse. Cell Death Dis 2010; 1: e24.

59. Bradner JE, West N, Grachan ML, Greenberg EF, Haggarty SJ, Warnow T et al. Chemical phylogenetics of histone deacetylases. Nat Chem Biol 2010; 6: 238-243.

60. Neuhoff V, Philipp K, Zimmer HG, Mesecke S. A simple, versatile, sensitive and volumeindependent method for quantitative protein determination which is independent of other external influences. Hoppe-Seyler's Z Physiol Chem 1979; 360: 1657-1670.

61. Deeti S, O'Farrell S, Kennedy BN. Early safety assessment of human oculotoxic drugs using the zebrafish visualmotor response. J Pharmacol Toxicol Methods 2014; 69: 1-8.

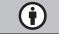

Cell Death and Disease is an open-access journal published by Nature Publishing Group. This work is licensed under a Creative Commons Attribution 4.0 International License. The images or other third party material in this article are included in the article's Creative Commons license, unless indicated otherwise in the credit line; if the material is not included under the Creative Commons license, users will need to obtain permission from the license holder to reproduce the material. To view a copy of this license, visit http://creativecommons.org/licenses/by/4.0/

C) The Author(s) 2017 